\title{
CAN SOCIAL MEDIA BE A TOOL FOR INCREASING TOURISTS' ENVIRONMENTALLY RESPONSIBLE BEHAVIOR?
}

\author{
Enamul HAQUE \\ Burapha University, Faculty of Management and Tourism, Bangsaen, Chonburi-20131, Thailand, e-mail: bpcsagar1346@gmail.com \\ Tinikan SUNGSUWAN* \\ Burapha University, Faculty of Management and Tourism, Bangsaen, Chonburi-20131, Thailand, e-mail: look_kook@ hotmail.com
}

Sarunya SANGLIMSUWAN

Burapha University, Faculty of Management and Tourism, Bangsaen, Chonburi-20131, Thailand, e-mail: sarunyas@ go.buu.ac.th

\begin{abstract}
Citation: Haque, E., Sungsuwan, T., Sanglimsuwan, S. (2021). CAN SOCIAL MEDIA BE A TOOL FOR INCREASING TOURISTS' ENVIRONMENTALLY RESPONSIBLE BEHAVIOR? GeoJournal of Tourism and Geosites, 38(4), $1211-1222$. https://doi.org/10.30892/gtg.38428-762
\end{abstract}

\begin{abstract}
For the sustainable development of a tourism destination, environmentally responsible behavior (ERB) is a vital issue. This study developed an implicated model based on the Stimulus-Organism-Response (S-O-R) framework showing the usages of social media by tourists regarded as a stimulus; environmental awareness, and place attachment generated from using social media regarded as an organism; and tourists' ERB thereby bringing behavioral intension regarded as responses. The integrated tourists' ERB model was experimentally tested using survey data from 467 Bangladeshi tourists by SEM-based methodology. The study found that social media has a beneficial effect on environmental awareness and place attachment, negatively impacting ERB. Furthermore, environmental awareness and place attachment has a favorable impact on ERB. This article discusses theoretical discoveries as well as practical consequences.
\end{abstract}

Key words: social media, environmental awareness, place attachment, ERB, Saint Martin's Island, Bangladesh

$* \quad * \quad * \quad * \quad * *$

\section{INTRODUCTION}

Tourism is often considered an essential mechanism for economic growth and development (Brida and Risso, 2009). The rapid growth of tourism sometimes has adverse environmental effects, such as increasing greenhouse gas emissions from visitors' leisure activities and needs (Dwyer et al., 2010). It has the key contribution to emit $\mathrm{CO}_{2}$ to the world climate, especially in the low-income country's tourism industry (Haseeb and Azam, 2020) and this industry is accounted for almost one-tenth of the world's carbon emissions (Independent, 2018). Since tourism is highly reliant on a destination's natural and cultural attractions (Kiatkawsin and Han, 2017), adverse tourist effects may severely affect sustainable development (Su et al., 2018). Tourists may cause to environmental damage by disrupting wildlife (Chen, 2011), polluting (Logar, 2010), and overcrowding (Dickinson and Robbins, 2008), even flower picking (Chang, 2010). One of the main concerns of tourism scholars is environmental protection. Tourists behavior is directly involve to degrade the natural environment (Kreag, 2001), caused different type of massive environment pollution (UNEP, 2019). Destination Management Organizations are increasingly faced with severe environmental problems (Cheng and Wu, 2015; Han, 2015) due to visitors' behavior (Chang, 2010). So, it is crucial to understand the primary factors of environmentally responsible behavior (ERB). Various theories were considered to understand the mechanism behind tourists' ERB, such as planned behavior (Chen and Tung, 2014), value-belief-norm theory (Han, 2015), goal-directed behavior (Han and Hwang, 2016), and place attachment theory (Cheng and $\mathrm{Wu}, 2015$ ). Different studies were held on tourists' ERB to explore tourists' internal drivers (Abdullah et al., 2019; Jahanishakib and Bakhshi, 2020), social and economic factors (Gifford and Nilsson, 2014; Liu and Hao, 2020), traditional education process (Bogner, 1998; Chawla and Cushing, 2007), and so on. Most of the typical studies focused on tourists' traits or social factors to find the ERB, ignoring the human internal learning process by digital platforms such as social media (SM).

We aimed to cover this gap using the well-known S-O-R framework of Mehrabian and Russell (1974). Globally, nearly 3.6 billion (49\% people) use social media which will be 4.141 billion by the year 2025 (Statista, 2020). Social media are increasingly important to grow the tourist's attractions (Briciu and Briciu, 2020), impactful for overshadowing all conventional outlets (Jacobsen and Munar, 2012), and a great influencer on tourists' beliefs and behavior (Lebe et al., 2014; Sparks et al., 2013). By focusing this area, we were attempting to explore the factors and their indicators which impacts on tourists' ERB, and then develop the ERB model using SEM. A stimulus may generate an internal state (i.e., gaining awareness of nature) which influence the person's conduct. Tourists may respond to environmental stimuli by developing subjective awareness about their entire tourism experience. The consumer then chooses whether to continue using the service or not (Taha et al., 2021). Tourists are more prone to adopt social media-related habits than visitors who have less integration and knowledge of the environment (Javed et al., 2020).

\footnotetext{
* Corresponding author
} 
The S-O-R framework helps predict consumer behavior, such as customer loyalty (Mazaheri et al., 2010). Some marketing and tourism academics have used the S-O-R framework to investigate the development of tourist behaviors, such as $\mathrm{Su}$ et al. (2014) revealed the importance of emotional experience in different tourism contexts. Others worked on hotel environment, which triggers hotel loyalty through emotions (Jani and Han, 2015), destinations reputation to visitors' behavior (Su et al., 2020), destination's experiences to Virtual Reality and visit intention (Kim et al., 2020).

SM marketing develops the purchasing intention (Oussa et al., 2021), substantial effect on behavioral intention and actual behavior (Javed et al., 2020) to its users. It affects increasing customer satisfaction which turns into repurchasing (Voramontri and Klieb, 2019) and revisiting (Riera et al., 2015). Having these influences, SM is becoming more significant in the tourism sector (Javed et al., 2020). However, SM can assist speed sustainable development by increasing eco-environmental consciousness (Lively, 2011). Similarly, place attachment (PA) is vital in predicting tourists' future behavior (Cheng et al., 2013). Environmental knowledge, place attachment and sensitivity influence ERB (Cheng and Wu, 2015; Lee and Oh, 2018). Place attachment has two dimensions: identity and dependency. Oh et al. (2012) found that place identity emerged after place dependency. However, environmental awareness (EA) is the driving factor underlying environmental behavior (Mobley et al., 2010). Environmental attitude leads to pro-environmental conduct (Burgess et al., 1998). Given the significance of EA and PA, the current research focused on social media's impact on visitors' ERB. In summary, this research seeks to understand how SM, EA, and PA affect tourist ERB.

The direct contributions of the study are; first, tourists' ERB enters the model to represent response outcomes in the SO-R framework (Figure 1). Secondly, this article integrates the S-O-R framework with script theory, using PA and EA to link the theories. Thirdly, by incorporating aspects of tourist behavioral psychology, the suggested model may enhance current consumer behavior theory and analytical frameworks. Finally, developing a new theoretical framework and platform for researching tourist's ERB origins, effects, and processes could inspire future scholars. Indirectly, by raising significant awareness to mass tourists on tourism sustainability, policymakers and destination management organizations (DMOs) may create more sustainable tourism. DMOs could build a good image using SM. The result may aid tourists and locals in better understand their environmental responsibilities. This study's S-O-R model may improve existing consumer behavior theory and analytical frameworks by integrating behavioral psychology and study aspects.

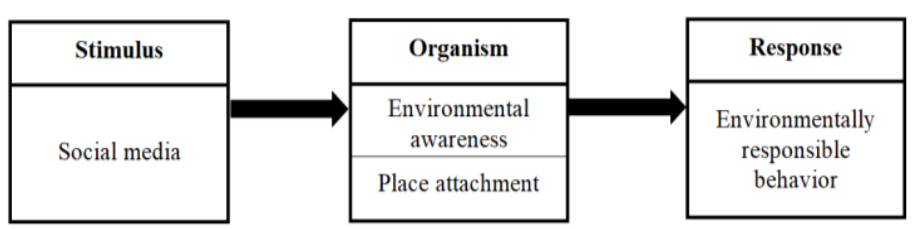

Figure 1. S-O-R model in research formed by researcher

\section{Theoretical foundation}

The Stimulus Organism Response (S-O-R) theory (Mehrabian and Russell, 1974) states that a stimulus generates a response based on an organism's internal evaluation. The internal evaluation may be conscious or unconscious. In every scenario, the internal tale drives unconscious or instinctive judgments that generate emotion and response. However, psychologically, it is Following S-O-R theory, people react to the environment in possible to alter human behavior deliberately or accidentally. two ways: approach behavior (desire to explore) or averting behavior (dislike to do anything positive). This approach focuses on the mental or emotional aspects of the environment, called aesthetic incitements (Wohlwill, 1976). Jacoby (2002) proposed an integrated S-O-R framework with cognitive and emotional structure. Kim and Lennon (2013) used the sources (externalinternal) of information as stimuli to influence customers' intentions (responses) through cognition and emotions (organism). Following the S-O-R framework, the actual theme park visitors' physical (hedonic and utilitarian values) experiences (Chang et al., 2014), the desire of travel and actual visits of travelers (Rajaguru, 2014) is explored. Recently, the S-O-R model has been applied in the hotel service consuming context (Jani and Han, 2015), on tourist perception to tourist ERB (Su et al., 2020), on tourist's experiences, reaction, and visiting intention (Kim et al., 2020). Following S-O-R framework, this study proposed that using SM (Stimuli) develop EA and empower PA (Organism) which lead tourists' ERB (Response).

\section{LITERATURE REVIEW AND HYPOTHESIS BUILDING}

\section{Stimuli: social media (SM) and its usages}

Social media are web-based platforms where people may interact, share information, and exchange ideas (Dollarhide, 2020). SM is a set of tools and resources that allow people to generate and share knowledge (Boyd, 2010). Because of the influence of SM in tourism, travel intent and purpose have impacted visitor behavior (Zeng and Gerritsen, 2014). The high use of SM by young tourists (Crowdriff, 2020) profoundly affects them (Chatzigeorgiou, 2017). Using social media/networks, tourists become co-producers, co-marketers, and co-consumers of tourism (Fotis, 2015). Tourism satisfaction (Huang et al., 2017), tourist decision (Chung et al., 2017), tourists motivation (Ho and Gebsombut, 2019) are the impact of SM which is normative (Chung and Han, 2017). Young tourists are captivated by SM channels worldwide (Crowdriff, 2020). SM has now surpassed all other sources of tourism information (Jacobsen and Munar, 2012). Consequently, visitors' attitudes and behavior have changed, and SM's influence in online tourism is growing (Xiang and Gretzel, 2010). SM increase environmental consciousness, which speeds up sustainable development (Lively, 2011). By producing, sharing, and distributing content, SM applications connect individuals to online communities (Jussila et al., 2011). Many environmental campaigns have used social media to inspire people to sign petitions, share news, and raise awareness (Kaur, 2015). Idumange (2012) argues that SM may reach a broad audience and build EA. Previously, tourist information came from recollection, brochures, guides, travel agencies, journals, and friends (Blackwell et al., 2006). But lately, SM has overtaken all other tourist sources (Jacobsen and Munar, 2012). 
The significant interaction of interpersonal and media with local communities suggests a specific linkage between SM and PA. It happens firstly; internet platforms let local community connects to interact (Castells, 2011); secondly, the interaction follows Person-Process-Place (personal, psychological, and geographical) paradigm, different from the traditional Man-Land connection (Scannell and Gifford, 2010). Psychological mechanisms mediate social media's vast space. Social networking may enhance PA and local ties by searching information which assists the tourists to plan (Snepenger et al., 1990), minimize confusion, and improve travel quality (Fodness and Murray, 1997). Hollander and Page (2020) found SM to be an effective tool for better understanding PA. SM promote EA, and it helps sustainable development (Lively, 2011). SM modifies the PA-ERB link (Xu and Han, 2019). So, we have reason to speculate:

$\mathrm{H}_{1}$ : SM might positively impact creating EA among tourists.

$\mathrm{H}_{2}$ : The usages of SM would positively and significantly impact PA to the tourists.

\section{Organism: Environmental awareness (EA) \& place attachment (PA)}

EA is based on two concepts a) a collection of feelings and ideas about the interaction of conduct and environment (Kollmuss and Agyeman, 2002), b) the concept of environment and its problems (Uehara et al., 2016). EA and interpersonal relationships of travelers also decide their perceived consistency, environmental attitude and behaviors. SM connects the users within a virtual community (Zeng and Gerritsen, 2014), the interaction of virtual communal platforms may increase environmental consciousness in many ways (Idumange, 2012). Burgess et al. (1998) assumed that environmental knowledge leads to an environmental attitude, resulting in pro-environmental behavior. Thus, EA is a multidimensional construct, which consists of affective (e.g., concern or attitude), cognitive (e.g., knowledge), and conative (e.g., behavioral intention) factors, as Kollmuss and Agyeman (2002) proposed. Individual's attachments to a place are named PA (Yuksel et al., 2010). PA is a multi-dimensional description of a person's cognitive process and location (Scannell and Gifford, 2010). Leisure tourism researchers evaluated place identity and place dependency for PA (Kyle, et al., 2003). Though, place identification and place dependency influence the dependent variable differently (Budruk et al., 2009). For example, Kyle et al. (2004) discovered that the Appalachian Trail's circumstances were more problematic than location dependency. Place identity probably weighs more than place dependency the connection between people and place (Payton et al., 2005). However, PA can describe by place identity \& dependence (Oh et al., 2012).

Ar1 and Yilmaz (2017) found that EA is related to people's motivation and behavioral intention to be pro-environmental. Chan (2001) predicted that environmental knowledge encourages eco-friendly behavior. For example, Ellen et al. (1991) found that environmental concerns influence diverse ERB, including composting and sustainable green consumption. Furthermore, studies believed that PA predicts ERB (Pietilä and Fagerholm, 2016). PA is also important in tourist forecasting and natural resource management (Warzecha and Lime, 2001). Many research focused on people's environmental actions in their former homes. Individuals develop a sense of place and engage in ERB and PA (Hines et al., 1987). Gosling and Williams (2010) argued that people connected to a place should voice their environmental concerns and become more aware of environmental problems. This concept leads to the following hypothesis.

$\mathrm{H}_{3}$ : The EA might have a significant direct effect on tourists' ERB.

$\mathrm{H}_{4}$ : The PA might significantly affect tourists' ERB.

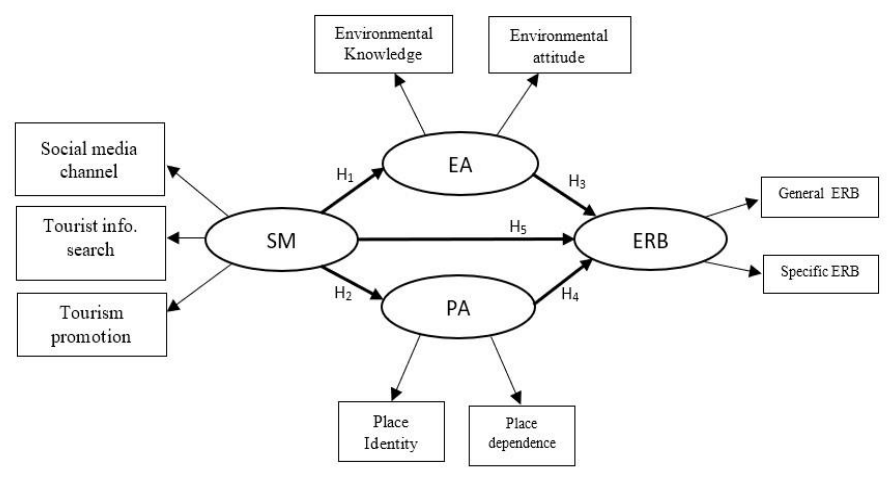

Figure 2. Research framework

\section{Response: Environmentally responsible behavior of tourists \\ Environmentally Responsible Behavior (ERB)} is a particular expression representing "any activity, person or community, aimed at environmental problems/problems" (Sivek and Hungerford, 1990). Tourists who participate in ERB will mitigate their impact on the environment (Kollmuss and Agyeman, 2002) and take environmental measures (Steg and Vlek, 2009). ERB is also deemed a crucial driver for good eco-tourism and sustainable growth (Lee et al., 2015). The measures of environmental behaviors are classified into six categories by Smith-Sebasto and D'Costa (1995):

civic action, educational action, financial action, legal action, physical action, and persuasive action. Researchers (Cottrell, 2003; Vaske and Kobrin, 2001) have divided ERB into two sub-categories that is general ERB (encouraging family and friends to practice ERB) and specific ERB (recycling, buying green goods; using alternative types of transportation). Tourists show ERB through showing environmental activism and environmentally aware activities in their private life (Stern, 2000). Javed et al. (2020) founded direct and indirect impacts of tourists' ERB by SM. SM have modified visitor recycling behavior (Sujata et al., 2019), reconstructed consciousness (Nalewajek and Macik, 2013), and developed ERB (Robelia et al., 2011). Previously, visitor information channels tended to look into previous memories, brochures, guides, travel agencies, journals and relatives and family (Blackwell et al., 2006). Moreover, SM also overshadowed all conventional outlets as a medium for tourist information queries (Ho and Liu, 2005; Jacobsen and Munar, 2012). SM users are optimistic towards online interactions to produce mutual information rather than 
receiving messages passively from websites (Hvass and Munar, 2012). The information created by social media users will persuade people to influence their beliefs and behavior, eventually (Lebe et al., 2014). In this way, it may rightly be assumed that:

$\mathrm{H}_{5}$ : SM might significantly affect to the ERB of tourists.

\section{MATERIALS AND METHODS}

In this section, we provided the items defining survey constructs. Next, we provided our data collecting method from the tourists of St. Martin's Island, a well-known tourism destination in Bangladesh. Subsequently, we express our data analysis approach.

\section{Questionnaire design}

After research modeling, we developed a questionnaire for a pilot study that included all of the original questions from the different sources. Thirty-five participants were asked to give feedback on the draft survey's question items. We also checked each scale's reliability (e.g., Cronbach's alpha and item-total statistics). Statistical analysis revealed excellent reliability (.91) and internally consistent validity (Cronbach's alpha values between 0.28 and 0.68 ). The question pools were condensed based on the pilot study's exploratory data analysis (to avoid likely respondent fatigue and incompleteness). Before participating in the pilot test, all respondents were pre-screened for recent tourist experiences and social media usage. We then described the source of survey question items. Three observed variables were used to measure SM; each observed variable had three items adapted from the study of Javed et al. (2020). Based on the study of (Kollmuss and Agyeman, 2002), EA is categorized by two observed variables named environmental knowledge and environmental attitudes. These two variables were measured by eight items which were taken from the study of (Cheng and Wu, 2015), (Severo et al., 2019), and (Lee and Jan, 2015). PA had two observed namely; Place identity and place dependence, taken from Budruk et al. (2009); Payton et al. (2005). The eight items of PA are cited from the study of Cheng and Wu (2015); Zhou et al. (2020) and (Lee, 2011). For the ERB scale, depending on Smith-Sebasto (1992) and Lee et al. (2013), two observed variables were founded: General behavior and specific behavior. Eleven items are taken from the study of (Cheng and Wu, 2015); (Su et al., 2020); (Lee, 2011); (Zgolli and Zaiem, 2018); (Lee et al., 2013); (Li et al., 2020), and (He et al., 2018) for measuring ERB. The scales ranged from "Extremely disagree" (1) to "Extremely agree" (5).

\section{Sample design and data collection}

The research conducted an online survey to get data from tourists who used SM and had visited St. Martin's Island, a renowned natural and environmentally diverse sensitive destination in Bangladesh's largest tourist metropolis (Cox's Bazar). The island's biodiversity includes 234 fish species, 187 mollusk species, 66 coral species, two seagrass species, 133 seaweed species, three mangrove species, 130 coastal and land birds, four marine turtle species, five sea snake species, nine marine mammals, and many terrestrial animals and plants (Ahammed et al., 2016). Four volunteered research assistants (university students) were trained and informed on the study's objectives, backgrounds, and data collecting procedure of research. Each data collector was allocated to a specific online SM travel group to ask the respondents to participate in the online survey politely. Notably, the research assistants ensured the respondents about the questionnaire's anonymity and personal information disclosures. The respondents were also assured that the survey data would only be handled for academic research and not for commercial purposes. After agreeing, the researcher assistant sends the Google form URL of the questionnaire to respondents. We formed the questionnaire in English; however, we provided a local language version for better understanding. After two weeks of delivering the questionnaire, the researcher followed up progress. The individuals who did not respond within three weeks were removed from the sample list. The online survey was conducted from May to June 2021. The research assistants were dutiful to clarify questions and were not influenced by respondents. Once filled out, the questionnaire was sent to the researcher's server. The sample size for analyzing the data using SEM, 250 to 500 indicates good (Schumacker and Lomax, 2016). Following this suggestion researchers targeted at least 450 respondents and sent the 500 surveys to the four largest online travel groups in Facebook as mostly used social media in Bangladesh namely: Travelers of Bangladesh-ToB (1.1 million members), Tour Group BD (811,000 members), Travellers of Bangladesh (411,000 members), and Bitto Travel and Tourism (50,000 members). Within 500 respondents, 482 respondents replied where 467 were suitable (93.4\% valid response) for analyzation. In the research, we applied a purposive sampling technique using screening questions asking the respondents about using social media in their daily life and the traveling experience to visit the island. After getting the positive answer, the google link was sent to the respondents to participate in the online survey.

\section{Data analysis}

After completing the data collection, the researcher focused on data processing and analysis using SPSS. First, we examined the descriptive data, then tested normality. After that appeared the correlation between variables. A measurement model was then performed to measure the model's quality. The SEM method was used to evaluate the fit of data and theoretical model then the model's hypotheses were tested.

\section{RESULTS AND DISCUSSION}

The general features of the respondents related to demographic characteristics was described in this section. After that, the construct reliability and validity were checked along with confirmatory factor analysis to measure the model.

\section{Sample analysis}

Table 1 shows the demographics of the research sample. Among participants mainly are young (45.40\%) with males 
(79.44\%) and females (20.56\%). Principally are educated with higher secondary school certificate (38.80\%), and master degree $(35.10 \%)$. A rambling income distribution revealed that the majority of individuals had no income $(52.46 \%)$ or less income (19.71\%). Mostly use Facebook (84.80\%) as SM by smartphone (93.58\%) for a long time (>5 years$65.95 \%)$. Most participants $(83.75 \%)$ have notable travel experience.
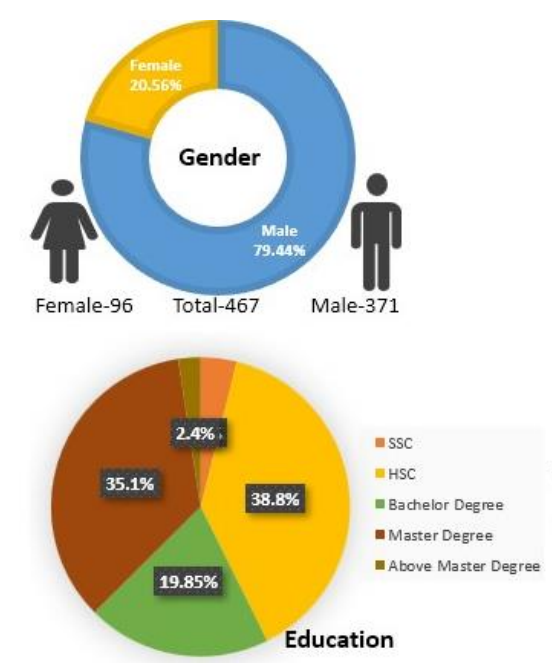
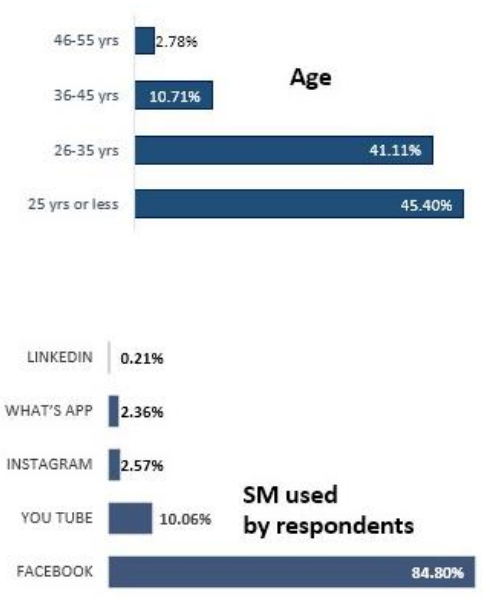

Figure 3. Samples in graphs \& charts
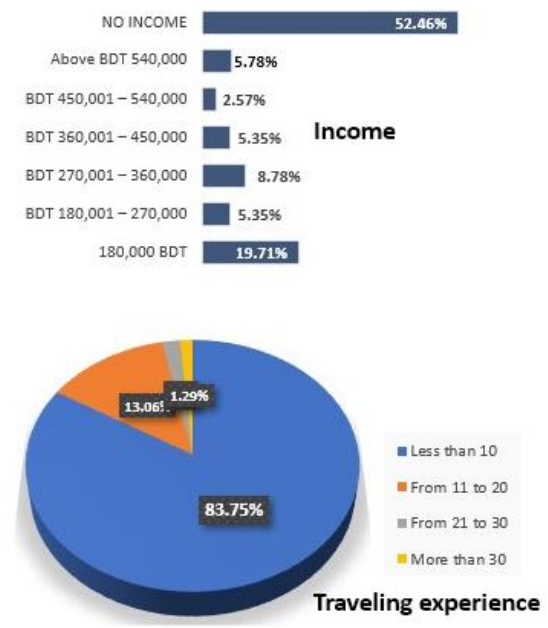

Table 1. Demographic data of participants

\begin{tabular}{|c|c|c|c|c|c|c|c|}
\hline \multicolumn{2}{|r|}{ variables } & $\mathrm{n}$ & $\%$ & \multicolumn{2}{|r|}{ variables } & $\mathrm{n}$ & $\%$ \\
\hline \multirow{2}{*}{ Gender } & Female & 96 & 20.56 & \multirow{5}{*}{$\begin{array}{c}\text { Type of using } \\
\text { SM }\end{array}$} & Facebook & 396 & 84.80 \\
\hline & Male & 371 & 79.44 & & You Tube & 47 & 10.06 \\
\hline \multirow{4}{*}{ Age } & 25 Years or less & 212 & 45.40 & & Instagram & 12 & 2.57 \\
\hline & $26-35$ Years & 192 & 41.11 & & What's app & 11 & 2.36 \\
\hline & $36-45$ Years & 50 & 10.71 & & LinkedIn & 1 & 0.21 \\
\hline & $46-55$ Years & 13 & 2.78 & \multirow{4}{*}{$\begin{array}{c}\text { Years of using } \\
\text { SM }\end{array}$} & Less than 1 years & 24 & 5.14 \\
\hline \multirow{5}{*}{ Education } & Secondary School Certificate (SSC) & 18 & 3.85 & & $1-3$ years & 49 & 10.49 \\
\hline & Higher Secondary School Certificate (HSC) & 181 & 38.80 & & $3-5$ years & 86 & 18.42 \\
\hline & Bachelor Degree & 93 & 19.85 & & More than 5 years & 308 & 65.95 \\
\hline & Master Degree & 164 & 35.10 & \multirow{4}{*}{$\begin{array}{l}\text { Devices for } \\
\text { using SM }\end{array}$} & Smartphone & 437 & 93.58 \\
\hline & Above Master Degree & 11 & 2.40 & & Desktop/Laptop & 27 & 5.78 \\
\hline \multirow{7}{*}{ Income } & $\leq$ BDT 180,000 & 92 & 19.71 & & Tablet & 1 & 0.21 \\
\hline & BDT 180001- 270,000 & 25 & 5.35 & & Others & 2 & 0.43 \\
\hline & \begin{tabular}{|l} 
BDT 270,001- 360,000 \\
\end{tabular} & 41 & 8.78 & \multirow{5}{*}{$\begin{array}{l}\text { Travelling } \\
\text { Experience }\end{array}$} & Less than 10 destinations & 391 & 83.75 \\
\hline & BDT 360,001- 450,000 & 25 & 5.35 & & \begin{tabular}{|l|}
$11-20$ destinations \\
\end{tabular} & 61 & 13.06 \\
\hline & \begin{tabular}{|l|} 
BDT 450,001- 540,000 \\
\end{tabular} & 12 & 2.57 & & $21-30$ destinations & 9 & 1.93 \\
\hline & Above BDT 540,001 & 27 & 5.78 & & More than 30 destinations & 6 & 1.29 \\
\hline & No income & 245 & 52.46 & & & & \\
\hline
\end{tabular}

\section{Measuring the model}

\subsection{Confirmatory factor analysis (CFA)}

A descriptive statistical analysis of all indicators should be run before evaluating data for CFA and SEM (Hair, 2009). The coefficients of variation (17.39 to 33.76), Skewness ( $₫ 2.15)$, and Kurtosis ( $₫ 5.22)$ were all significant at the .01 level. After ensuring the data was normal, CFA was used to assess the inter-item correlation of structural components and dimensions of the structure. CFA model fit indices showed how well it matched the data. $\chi^{2}$, NFI, CFI, RMSEA, and CMIN/DF values were considered to assess goodness-of-fit (Abubakar and Ilkan, 2016).

A measurement model's acceptable $\chi^{2} / \mathrm{df}$ value is $\leq 3$ (Johnson et al., 1995). The $\chi^{2} / \mathrm{df}$ score was 1.078; RMSEA= $0.013<0.05, \mathrm{GFI}=0.95, \mathrm{NFI}=0.96, \mathrm{CFI}=0.99$, TLI=0.99, and AGFI=0.92 which is acceptable by Schumacker and Lomax (2016). As a consequence, the measurement model fits the data well.

\subsection{Construct reliability and validity}

Construct reliability and validity were tested to demonstrate inter-item consistency and connections of the model's latent variables. Composite reliability measures the internal consistency of observable variables or items (Netemeyer et al., 2003). It's a metric of the observed variables' shared variance used to find a latent construct (Fornell and Larcker, 1981). Tseng et al. (2006) suggest a criterion of 0.60 or up for composite reliability. Cronbach's alpha and composite construct reliability were used to evaluate measuring reliability. The Cronbach's alpha of constructs varies from 0.87 to 0.92 (Table 2). Composite reliability spans from 0.75 to 0.89 , which is higher than cutoff 0.60 . For each construct, it ensures appropriate internal consistency by Tseng et al. (2006). Convergent and discriminant validity are two aspects of construct validity. Convergent refers to the measurements of how closely it correlates with other variables. Discriminant validity, on the other hand, is a measure of how remotely linked constructs are. The cutoff of convergent validity is 
>.50, or if the AVE is higher than the squired correlations between any two constructs, it is satisfied (Fornell and Larcker, 1981). It was determined that all item factor loadings were more than or equal to 0.52 with a significance level of 0.01, indicating satisfied convergent validity (Anderson and Gerbing, 1988). The AVE was 0.57-0.79 (cutoff 0.50), which explained that constructs are significant in the variables (Fornell and Larcker, 1981). All of this shows measure convergent validity. Discriminant validity is substantial if the AVE squire root between two constructs is higher than the correlation (Fornell and Larcker, 1981). There are no correlation coefficients more than 0.74 and no squire roots of AVEs less than 0.75 (Table 3), suggesting that the scales in this research are discriminately valid. So, the measurement model consists of 4 latent variables consequently SM ( 3 observed variables with 9 items), EA ( 2 observed variables with 8 items), PA ( 2 observed variables with 8 items), and ERB ( 2 observed variables with 11 items) (Table 2).

Table 2. Empirical results of the measurement model

\begin{tabular}{|c|c|c|c|c|c|c|c|c|c|}
\hline Construct & Observed & Observed Items & Mean & SD & \begin{tabular}{|c|}
$\mathrm{F}$. \\
loading
\end{tabular} & \begin{tabular}{|c|}
$\mathrm{C}$. \\
Reliability
\end{tabular} & AVE & $\begin{array}{c}\sqrt{ } \\
\text { AVE }\end{array}$ & Alpha \\
\hline \multirow{9}{*}{ SM } & \multirow{3}{*}{$\begin{array}{l}\text { Social } \\
\text { media } \\
\text { channel }\end{array}$} & Actively users of social media channels & 3.49 & 0.94 & 0.74 & \multirow[t]{9}{*}{0.92} & \multirow[t]{9}{*}{0.57} & \multirow[t]{9}{*}{0.75} & \multirow[t]{9}{*}{0.87} \\
\hline & & Actively upload contents in social media & 3.73 & 0.88 & 0.84 & & & & \\
\hline & & Impacts of social media while travelling & 3.14 & 1.06 & 0.61 & & & & \\
\hline & \multirow{3}{*}{$\begin{array}{l}\text { Tourism } \\
\text { promotion }\end{array}$} & Promoting/advertising tourism activities & 3.92 & 0.77 & 0.78 & & & & \\
\hline & & Assessment of social media to led promoting tourism & 4.06 & 0.81 & 0.76 & & & & \\
\hline & & Environment protection by the announcement in SM & 4.01 & 0.78 & 0.75 & & & & \\
\hline & \multirow{3}{*}{\begin{tabular}{|l|} 
Tourist \\
information \\
search
\end{tabular}} & Importance of SM for searching information and making decision & 4.10 & 0.80 & 0.81 & & & & \\
\hline & & SM helps searching authentic and reliable information & 3.81 & 0.82 & 0.79 & & & & \\
\hline & & Searching external information for new destination & 3.84 & 0.80 & 0.68 & & & & \\
\hline \multirow{8}{*}{ EA } & \multirow{3}{*}{$\begin{array}{l}\text { Env. } \\
\text { knowledge }\end{array}$} & Knowledgeable to the maintenance of ecological balance & 4.02 & 0.81 & 0.76 & \multirow[t]{8}{*}{0.89} & \multirow[t]{8}{*}{0.71} & \multirow[t]{8}{*}{0.84} & \multirow[t]{8}{*}{0.89} \\
\hline & & Natural resources of islands should protect for future & 4.42 & 0.85 & 0.72 & & & & \\
\hline & & The impact of activities on the natural environments & 3.92 & 0.88 & 0.71 & & & & \\
\hline & \multirow{5}{*}{$\begin{array}{l}\text { Env. } \\
\text { attitude }\end{array}$} & Usual activities on environmental issues & 3.91 & 0.78 & 0.70 & & & & \\
\hline & & Feelings of motivation for adopting improved env. attitudes & 4.06 & 0.73 & 0.82 & & & & \\
\hline & & Raising environmental protection awareness & 4.37 & 0.76 & 0.69 & & & & \\
\hline & & Humans interfere to nature produces disastrous consequences & 4.21 & 0.85 & 0.59 & & & & \\
\hline & & Humans will eventually learn about how nature works & 4.32 & 0.82 & 0.72 & & & & \\
\hline \multirow{8}{*}{ PA } & \multirow{4}{*}{$\begin{array}{l}\text { Place } \\
\text { Identity }\end{array}$} & Feelings of touring in the destination & 4.05 & 0.84 & 0.75 & 0.93 & 0.79 & 0.89 & 0.91 \\
\hline & & Feelings to learn about the destination by revisiting & 4.15 & 0.83 & 0.83 & & & & \\
\hline & & Sense of belonging concerning the island & 3.79 & 0.86 & 0.78 & & & & \\
\hline & & Personal feeling about the island & 3.75 & 0.91 & 0.70 & & & & \\
\hline & \multirow{4}{*}{$\begin{array}{l}\text { Place } \\
\text { dependence }\end{array}$} & Intend to spend more time in the destination & 3.72 & 0.89 & 0.75 & & & & \\
\hline & & Enjoyment in traveling to island more than other destinations & 3.75 & 0.90 & 0.89 & & & & \\
\hline & & Satisfaction of visiting island than another place & 3.73 & 0.85 & 0.91 & & & & \\
\hline & & Finding substitute of this destination & 3.47 & 0.95 & 0.75 & & & & \\
\hline \multirow{11}{*}{ ERB } & \multirow{5}{*}{$\begin{array}{l}\text { General } \\
\text { behavior }\end{array}$} & Willingness to solve the environmental problems of the island & 3.87 & 0.82 & 0.82 & \multirow[t]{11}{*}{0.93} & \multirow[t]{11}{*}{0.73} & \multirow[t]{11}{*}{0.86} & \multirow[t]{11}{*}{0.92} \\
\hline & & Reading about the environments of the island & 3.57 & 0.83 & 0.67 & & & & \\
\hline & & Status of convincing the travel companions to the island & 3.84 & 0.80 & 0.76 & & & & \\
\hline & & Buying environmentally sound product & 3.91 & 0.79 & 0.73 & & & & \\
\hline & & Intentions to learn more about the local environment & 3.91 & 0.76 & 0.81 & & & & \\
\hline & \multirow{6}{*}{$\begin{array}{l}\text { Specific } \\
\text { behavior }\end{array}$} & Efforts to learn more about culture of island & 3.82 & 0.78 & 0.81 & & & & \\
\hline & & Activities to reduce the interference the nature of island & 3.85 & 0.81 & 0.80 & & & & \\
\hline & & Following the legal ways for stopping the destruction of island & 3.81 & 0.81 & 0.74 & & & & \\
\hline & & Garbage related action while visiting the island & 3.81 & 0.87 & 0.70 & & & & \\
\hline & & Willingness to lessen/stop visiting the island if it is needed & 3.75 & 0.88 & 0.52 & & & & \\
\hline & & Measuring the environmental damaging activity while travelling & 4.18 & 0.83 & 0.72 & & & & \\
\hline Goodness-c & f-fit indices & $\chi^{2}=427.26, d f=397, \chi^{2} / d f=1.078, p=.142, G F I=.952, A G F I=$ & $=.92, R \lambda$ & $M S E$ & $=.013$, & & & & \\
\hline
\end{tabular}

\subsection{Structural model analysis}

\subsubsection{Correlation coefficient of variables}

The correlation of all variables in SEM was significant at the statistical level p<.01. According to Schober et al. (2018), the correlation of $<0.1$ indicate negligible where $>0.9$ indicate very strong correlation. The lowest correlation was between SM and PA (.58) and the highest correlation was between EA and ERB (.74) (Table 3). These correlation coefficients indicated that the data are good enough for analyzing with the structural equation modeling.

Table 3. The correlation and AVEs of variables

\begin{tabular}{|c|c|c|c|c|}
\hline Variable & SM & EA & PA & ERB \\
\hline SM & .75 & & & \\
\hline EA & $.71^{* *}$ & .84 & & \\
\hline PA & $.58^{* *}$ & $.61^{* *}$ & $\mathbf{. 8 9}$ & \\
\hline ERB & $.62^{* *}$ & $.74^{* *}$ & $.73^{* *}$ & $\mathbf{. 8 6}$ \\
\hline
\end{tabular}

Table 4. The model fit indices of the ERB model

\begin{tabular}{|l|l|l|l|}
\hline \multicolumn{1}{|c|}{ Criteria Index } & Model fit criteria & \multicolumn{1}{c|}{ Scores } & Results \\
\hline Chi-Square $\left(\chi^{2}\right)$ & $p>.05$ & $\chi 2=22.84(p=.08)$ & Passed \\
\hline $\boldsymbol{\chi 2} / \boldsymbol{d} \boldsymbol{f}$ & $<2$ & 1.43 & Passed \\
\hline $\boldsymbol{R M S E A}$ & $<.05$ & .03 & Passed \\
\hline SRMR & $<.05$ & .01 & Passed \\
\hline $\boldsymbol{G F I}$ & $>.95$ & .98 & Passed \\
\hline $\boldsymbol{C F I}$ & $>.95$ & .99 & Passed \\
\hline $\boldsymbol{N F I}$ & $>.95$ & .99 & Passed \\
\hline
\end{tabular}




\subsubsection{Goodness-of-fit indices}

The value of $\chi 2$, GFI, NFI, CFI, RMSEA, SRMR, CMIN/DF ( $\left.\chi^{2} / \mathrm{df}\right)$ values are considered to evaluate the goodness-of-fit indices (Abubakar and Ilkan, 2016). The acceptable $\chi^{2} / \mathrm{df}$ value of a measurement model is $\leq 3$ (Johnson et al., 1995). The value of Chi-Square equal to 22.84, $d f=16, \chi^{2} / d f=1.43$, RMSEA=.03, CFI=.99, GFI= 0.98, SRMR=0.01, NFI=0.99 (Table 4). According to the suggestion of model fit criteria of Schumacker and Lomax (2016), the proposed model perfectly fits (Table 4).

\subsection{Hypothesis testing}

Table 5 shows structural path model result proposed in this study. The effect of SM on EA $(\beta=0.92, p<.01)$; SM on PA $(\beta=0.70, \mathrm{p}<.01)$; EA on tourists' ERB $(\beta=0.84, \mathrm{p}<.01)$, and place attachment's effect on tourists' ERB $(\beta=0.58, \mathrm{p}<.01)$, which suggested that $\mathrm{H} 1, \mathrm{H} 2, \mathrm{H} 3$, and $\mathrm{H} 4$ were supported. Therefore, the direct effects of SM on tourists' ERB at $\beta=-.43$ (indirect effects $\beta=1.17$, total effects $\beta=.75$ ) at value $\mathrm{p}<.01$, which also support the $\mathrm{H} 5$, though it has significant negative effects but still positive in total and indirect effects to ERB.

Table 5. Hypothesis testing result $(* p<.01)$

\begin{tabular}{|c|l|c|c|c|}
\hline SL & \multicolumn{1}{|c|}{ Hypothesis } & Path & $\begin{array}{l}\text { Std. Path } \\
\text { loading }\end{array}$ & Conclusion \\
\hline $\mathrm{H}_{1}$ & $\begin{array}{l}\text { Social media } \rightarrow \\
\text { Environmental } \\
\text { awareness }\end{array}$ & $\beta$ & $0.92^{*}$ & Supported \\
\hline $\mathrm{H}_{2}$ & $\begin{array}{l}\text { Social media } \rightarrow \\
\text { Place attachment }\end{array}$ & $\beta$ & $0.70^{*}$ & Supported \\
\hline $\mathrm{H}_{3}$ & $\begin{array}{l}\text { Environmental } \\
\text { awareness } \rightarrow \text { ERB }\end{array}$ & $\beta$ & $0.84^{*}$ & Supported \\
\hline $\mathrm{H}_{4}$ & $\begin{array}{l}\text { Place attachment } \\
\rightarrow \text { ERB }\end{array}$ & $\beta$ & $0.58^{*}$ & Supported \\
\hline $\mathrm{H}_{5}$ & $\begin{array}{l}\text { Social media } \rightarrow \\
\text { ERB }\end{array}$ & $\beta$ & $-0.43^{*}$ & Supported \\
\hline
\end{tabular}

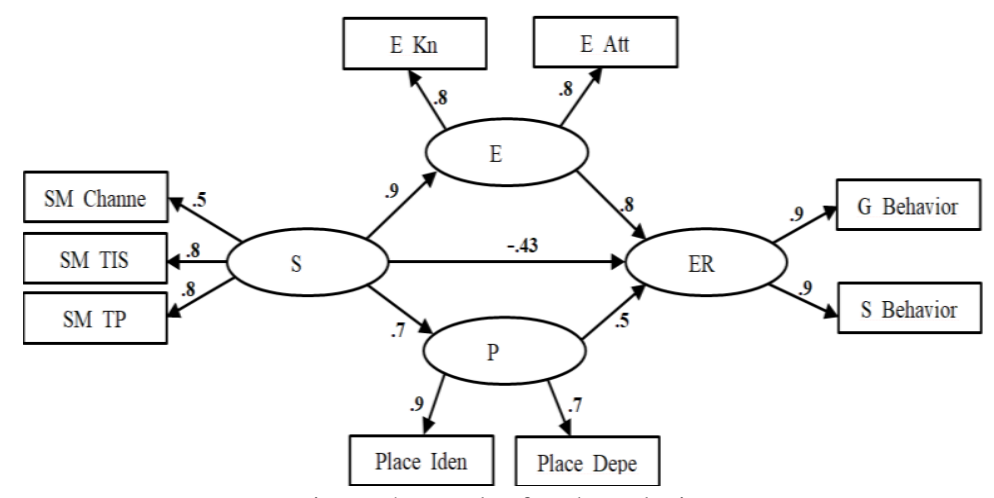

Figure 4. Result of path analysis

\subsection{Analysis of model}

It is worthy to note that the current study also examined the model that includes the three key components in the typical S-O-R framework and the ERB variables (from the proposed theory). The value of $\chi 2 /$ df was 1.43 (cutoff less than 3.00); RMSEA $=0.03<0.05 ; \mathrm{SRMR}=0.01<.05 ; \mathrm{GFI}=0.98, \mathrm{NFI}=0.99, \mathrm{TLI}=0.99, \mathrm{CFI}=0.99$ all of which were greater than the 0.95 cutoff suggested by Schumacker and Lomax (2016). As Fig. 4 shows, the effect of SM on EA ( $\beta=0.92, p<.01)$; SM on PA $(\beta=0.70, \mathrm{p}<.01)$; EA on $\operatorname{ERB}(\beta=0.84, \mathrm{p}<.01)$, PA's effect on tourists' $\mathrm{ERB}(\beta=0.58, \mathrm{p}<.01)$, and $\mathrm{SM}$ to $\mathrm{ERB}(\beta=-0.43, \mathrm{p}$ $<.01)$. The model explained $90 \%, 84 \%, 49 \%$, and $84 \%$ of SM, EA, PA, and ERB variance, respectively. This competing model appears to be reasonable to predict tourist ERB based on the fit indices and path coefficient.

\section{CONCLUSION}

\section{Discussion}

Prior research established the statistical significance of the research results. The ERB model of SM users showed high goodness of fit (Schumacker and Lomax, 2016). The study found that SM widespread pressing EA and PA may cause ERB in tourists. Jussila et al. (2011) and Lee and Ma (2012) showed that users might share, communicate, and collaborate their ideas and experiences by creating and distributing material (media and text). Idumange (2012) recommended using popular SM channels like blogs, Facebook, Twitter, and YouTube to increase EA. According to this study's structural path analysis, EA generated by SM may understand tourists' ERB. We had found the evidence (Idumange, 2012; Kaur, 2015) to support the conclusions. SM is also important since it affects place attachment and, therefore, tourist ERB. Travelers who use SM properly are more likely to develop positive opinions and help to develop the positive images to destinations to others and themself. The findings of this study make pervious research more concrete. The research looked at the effects of SM on place attachment. Xu and Han (2019) discovered that SM alters the relationship between place attachment and proenvironmental behavior. Hollander and Page (2020) showed emotional analysis to comprehend better PA perspectives utilizing SM. This research found an association between environmental awareness and tourist ERB. The results show that EA generated from using SM has a significant effect on ERB. According to Arı and Y1lmaz (2017), EA increases people's motivation and behavioral intention to be pro-environmental. Song et al. (2019) discovered that EA influences behaviors like purchasing green products. Cheng and $\mathrm{Wu}$ (2015) discovered that environmental awareness influences behaviors like purchasing green products. Other researchers found similar to this work including He et al. (2018); (Lee and Oh, 2018); Su et al. (2020). This study's results quantitatively support the significant effect of environmental awareness on ERB.

The study also explores that the place attachment raised from SM affects tourists' ERB, which upholds the previous research. According to Lee (2011), people attached to a place express environmental problems and become more conscious. The quantitative research of Pietilä and Fagerholm (2016) showed that place attachment is an ERB predictor. Cheng et al. (2013) founded visitors attached to islands are more inclined to show ERB.

This study's model shows the benefit of integrating EA and PA via social media to understand tourist ERB. It also backed up the integrated tourist behavior model based on S-O-R theory. DMOs are increasingly faced with severe environmental problems (Cheng and Wu, 2015; Han, 2015) due to visitors' behavior (Chang, 2010). Contents of SM 
affects tourist motivation and behavior (Javed et al., 2020), recycling behavior (Sujata et al., 2019), consumer awareness (Nalewajek and Macik, 2013), and developed ERB (Robelia et al., 2011). The research found that social media has substantially effects on tourists' ERB, which merged Javed et al. (2020) findings. Su et al. (2020) revealed that visitors' gathered experiences influence tourists' ERB. However, this study found that SM has significant direct and indirect impact on tourists' ERB which strengthen the findings of Javed et al. (2020). Though the direct impact is negatively and indirect impact is positively significant. Goh et al. (2013) founded that marketer-generated content has less influence on consumer behavior than user-generated content. Some researcher for example, Abbas et al. (2019) found the negative impact of using social media of student learning behavior. Taha et al. (2021) showed a significant difference in use of SM during the first wave of the COVID-19 pandemic which may impact on consumer behavior. However, the study showed that social media has significant influence on raising EA and generating PA to mass tourists' which significantly impact to tourists' ERB.

\section{Implication}

\section{Theoretical contribution}

The results supported the researcher's paradigm, which may be very fruitful for the tourism industry of Bangladesh and any other country with a similar context. Following the S-O-R theory, this research found some dimensions linked to SM and its influence on EA and PA, which impact tourists' behavioral intention and actual behavior. SM has unavoidable importance as a source of destination information and environmental attitudes among visitors when purchasing tourism goods. Furthermore, this research found that SM-generated EA and PA may significantly contribute to tourists' ERB. Our study suggested that the S-O-R framework may be defined by tourists' consumption, prompted by SM and results in EA and PA, with the visitors' ERB as the output. The findings provide a significant contribution to the understanding of consumer behavior in different nations, in other contexts, particularly in Bangladesh. As a result, the suggested approach may be applied to various developing-country contexts or destinations.

\section{Application contribution}

This study's sample was highly representative of visitors using the random sampling method. As a result, the study's findings may be used to enhance marketing campaigns and standardize mass tourism's environmental responsibilities via SM. Domestic travel in Bangladesh is dominated by young people, particularly those under 35 . The research found that Bangladeshi visitors use SM to exchange travel experiences and destination information. For developing SM, tourists are more informed and skilled in travel planning, exchanging experiences, and searching for attractions everywhere and anytime (Jin et al., 2014). Based on this finding, DMOs should utilize digital channels like SM to promote destinations, share information, increase EA, and attached to new places for all tourists, especially young people. The tourism marketers can focus on their targeted consumers specifically to young tourists to extend their market using SM platforms by sharing attractive and educative contents. Both DMOs and tourism policymakers should be aware of the findings of this study. To enhance the sustainability of tourism destinations and the tourism sector, DMOs and business managers should closely be careful with social media channels. Because of SM's importance, it is necessary to remain updated in providing relevant information and be available on such tourist information searches to the potential tourists. Notably, tourism promotion significantly affects visitor behavior, whereas SM has become essential for attracting tourists. In a competitive business context, DMOs and tourism policymakers should develop an appropriate marketing plan.

DMOs should develop policies and procedures (e.g., promoting eco-friendly practices and activities, exploring ecological complexity of the destination through social media) for environmentally sensitive destinations to raise EA and build good relationships with mass tourists. Social media is an excellent medium for linking mass visitors to a set of eco-friendly conservation activities. Destination eco-friendly marketing through SM may assist DMOs to create an effective strategy to nurture and increase visitors' ERB. DMOs should regularly post environmental awareness, ecological imbalance, visitor duties on the destination's website, and other social media verified sites. This activity will assist in increasing environmental awareness among mass tourists about recycling and eco-friendly tourism. The site can retain its competitive advantage by attracting (e.g., to social media travel communities) and reassuring visitors about the location's environmental problems. Tourists would have been wary of purported ecological initiatives. These activities will show the significance of environmental issues for the destination as well as the tourist industry. And finally, the goal of sustainable, eco-friendly development will be enriched both offline and online by tourists themselves. DMOs should Involve visitors in the early stages of functional attachment and encourage them to become emotionally attached to locations. Giving people good memories of a place may enhance their emotional connection (Ujang and Zakariya, 2015). Improving beach quality, recreational activities, and civic participation may attract mass visitors. It may also enhance tourist emotional connection. Lokocz et al. (2011) described PA as social and personal engagement to the destination. Including visitors in the maintenance of a destination's environment may assist create sustainable tourism plans. Tourists with a feel of location will take part in ERB, which will energize DMOs and policymakers. Environmentally aware tourists are more likely to join local conservation initiatives. Hearing from communities can help to create more effective environmental and tourism development plans (Shandas and Messer, 2008). DMOs shall also present signboards, interpretive programs, guided tours, environmental education activities, and printed and online information to preserve natural and cultural resources.

\section{Limitations and directions for future research}

In general, no studies are without limitation. This study contains some shortcomings. First, the ERB question items in this study may have overlooked some key elements that future research may explore. A more general ERB paradigm may 
categorize ERB components. Second, contrary to the results of this research, it seems that using social media to ERB has a direct positive connection. We think further study should delve into this. Third, examining moderating effects connected with sociodemographic characteristics may help strengthen the argument presented in this article and better understand the model variables' impact, which may be found by further research. Fourth, the sample is not representative of all site visitors. Moreover, visitor profiles may change time by time as individuals expect to see multiple activities. Consistency testing is complex with this convenience sample. Having some limitations of respondents (e.g., young aged, no income, somewhat educated, domestic tourists), the study's generalizability might be limited. The study's research methodology should be verified, such as semi-structured method, across cultures, tourism destinations, and settings (e.g., highly or moderate-income tourist, domestic tourist vs foreign tourist, including tourism-related scholars and people in business). Fifth, future studies may collect long-term data to examine the integrated model's other factors' effects on social media and ERB. Longitudinal data would enable future researchers to see how time impacts people's use of social media and their ERB and if the advantages of eco-tourism are long-lasting. Sixth, ERB may be measured before and after an experiment to see how visitors react to eco-friendly sites. Future researchers may utilize this kind of data to improve the model's causality argument. We encourage tourism scholars to look at these study options to broaden the scope of sustainable and eco-friendly tourism research. Finally, in the future, the researchers should include some more variables such as destination ecological reputations, psychological factors, tourists' perceptions and attitudes toward sustainable tourism development, and support for sustainable tourism development should be studied to determine ERB's causality.

\section{Acknowledgement}

This research was financially supported by the Thailand International Cooperation Agency (TICA), Ministry of foreign affairs, Thailand; advisory \& technically supported by Burapha university authority, Thailand (No. IRB 4-145; 27052564); and administrate backed by Ministry of civil aviation \& Tourism, Bangladesh (No. 30.00.0000.010.25.003.20-196; 31052021).

\section{REFERENCES}

Abbas, J., Aman, J., Nurunnabi, M., \& Bano, S. (2019). The impact of social media on learning behavior for sustainable education: Evidence of students from selected universities in Pakistan. Sustainability, 11(6), 1683. https://doi.org/10.3390/su11061683

Abdullah, S., Samdin, Z., Teng, P., \& Heng, B. (2019). The impact of knowledge, attitude, consumption values and destination image on tourists' responsible environmental behaviour intention. Management Science Letters, 9(9), 1461-1476. https://doi.org/10.5267/j.msl.2019.5.005

Abubakar, A. M., \& Ilkan, M. (2016). Impact of online WOM on destination trust and intention to travel: A medical tourism perspective. Journal of Destination Marketing \& Management, 5(3), 192-201. https://doi.org/10.1016/j.jdmm.2015.12.005

Ahammed, S., Hossain, M.A., Abedin, M., \& Khaleque, A. (2016). A study of environmental impacts on the coral resources in the vicinity of the Saint Martin island, Bangladesh. International Journal of Scientific \& Technology Research, 5(1), 37-39.

Anderson, J.C., \& Gerbing, D.W. (1988). Structural equation modeling in practice: A review and recommended two-step approach. Psychological bulletin, 103(3), 411-423. https://doi.org/10.1037/0033-2909.103.3.411

Ar1, E., \& Y1lmaz, V. (2017). Effects of environmental illiteracy and environmental awareness among middle school students on environmental behavior. Environment, development and sustainability, 19(5), 1779-1793. https://doi.org/10.1007/s 10668-016-9826-3

Blackwell, R., Miniard, P., \& Engel, J. (2006). Consumer behavior (10th eds.). Masao, OH: Thomson/Sount. https://doi.org/10.2307/1250212

Bogner, F.X. (1998). The influence of short-term outdoor ecology education on long-term variables of environmental perspective. The Journal of environmental education, 29(4), 17-29. https://doi.org/10.1080/00958969809599124

Boyd, D. (2010). Social network sites as networked publics: Affordances, dynamics, and implications. In A networked self, 47-66, Routledge. https://doi.org/10.4324/9780203876527-8.

Briciu, A., \& Briciu, V.A. (2020). Participatory culture and tourist experience: Promoting destinations through YouTube. In Strategic Innovative Marketing and Tourism, 425-433, Springer. https://doi.org/10.1007/978-3-030-36126-6_47.

Brida, J.G., \& Risso, W.A. (2009). Tourism as a factor of long-run economic growth: An empirical analysis for Chile. European Journal of Tourism Research, 2(2), 178-185.

Budruk, M., Thomas, H., \& Tyrrell, T. (2009). Urban green spaces: A Study of place attachment and environmental attitudes in India. Society \& Natural Resources, 22, 824-839. https://doi.org/10.1080/08941920802628515

Burgess, P.W., Alderman, N., Evans, J., Emslie, H., \& Wilson, B. (1998). The ecological validity of tests of executive function. Journal of the international neuropsychological society, 4(6), 547-558. https://doi.org/10.1017/S1355617798466037

Castells, M. (2011). The rise of the network society. John wiley \& sons, 12. https://doi.org/10.1002/9781444319514.

Chan, R. Y. (2001). Determinants of Chinese consumers' green purchase behavior. Psychology \& marketing, 18(4), $389-413$. https://doi.org/10.1002/mar.1013

Chang, C.H., Shu, S., \& King, B. (2014). Novelty in theme park physical surroundings: An application of the stimulus-organismresponse paradigm. Asia Pacific Journal of Tourism Research, 19(6), 680-699. https://doi.org/10.1080/10941665.2013.779589

Chang, L.C. (2010). The effects of moral emotions and justifications on visitors' intention to pick flowers in a forest recreation area in Taiwan. Journal of Sustainable tourism, 18(1), 137-150. https://doi.org/10.1080/09669580903215154

Chatzigeorgiou, C. (2017). Modelling the impact of social media influencers on behavioural intentions of millennials: The case of tourism in rural areas in Greece. Journal of Tourism, Heritage \& Services Marketing, 3(2), 25-29. https://doi.org/10.5281/zenodo.1209125

Chawla, L., \& Cushing, D.F. (2007). Education for strategic environmental behavior. Environmental education research, 13(4), 437-452. https://doi.org/10.1080/13504620701581539

Chen, C.L. (2011). From catching to watching: Moving towards quality assurance of whale/dolphin watching tourism in Taiwan. Marine Policy, 35(1), 10-17. https://doi.org/10.1016/j.marpol.2010.07.002

Chen, M.F., \& Tung, P.J. (2014). Developing an extended Theory of Planned Behavior model to predict consumers' intention to visit green hotels. International journal of hospitality management, 36, 221-230. https://doi.org/10.1016/j.ijhm.2013.09.006

Cheng, T.M., \& Wu, H.C. (2015). How do environmental knowledge, environmental sensitivity, and place attachment affect environmentally responsible behavior? An integrated approach for sustainable island tourism. Journal of Sustainable tourism, 23(4), 557-576. https://doi.org/10.1080/09669582.2014.965177 
Cheng, T.M., C. Wu, H., \& Huang, L.M. (2013). The influence of place attachment on the relationship between destination attractiveness and environmentally responsible behavior for island tourism in Penghu, Taiwan. Journal of Sustainable tourism, 21(8), $1166-1187$. https://doi.org/10.1080/09669582.2012.750329

Chung, N., \& Han, H. (2017). The relationship among tourists' persuasion, attachment and behavioral changes in social media. Technological Forecasting and Social Change, 123, 370-380. https://doi.org/10.1016/j.techfore.2016.09.005

Chung, N., Tyan, I., \& Chung, H.C. (2017). Social support and commitment within social networking site in tourism experience. Sustainability, 9(11), 2102. https://doi.org/10.3390/su9112102

Cottrell, S.P. (2003). Influence of sociodemographics and environmental attitudes on general responsible environmental behavior among recreational boaters. Environment and behavior, 35(3), 347-375. https://doi.org/10.1177/0013916503035003003

Crowdriff. (2020). How Travelers Use Social Media for Travel, Access on 07-11-2020. https://crowdriff.com/resources/blog/howtravelers-use-social-media-travel

Dickinson, J.E., \& Robbins, D. (2008). Representations of tourism transport problems in a rural destination. Tourism Management, 29(6), 1110-1121. https://doi.org/10.1016/j.tourman.2008.02.003

Dollarhide, E.M. (2020). Social media definition. access on 6th November 2020. https://www.investopedia.com/terms/s/social-media.asp

Dwyer, L., Forsyth, P., Spurr, R., \& Hoque, S. (2010). Estimating the carbon footprint of Australian tourism. Journal of Sustainable tourism, 18(3), 355-376. https://doi.org/10.1080/09669580903513061

Ellen, P.S., Wiener, J.L., \& Cobb-Walgren, C. (1991). The role of perceived consumer effectiveness in motivating environmentally conscious behaviors. Journal of public policy \& marketing, 10(2), 102-117. https://doi.org/10.1177/074391569101000206

Fodness, D., \& Murray, B. (1997). Tourist information search. Annals of tourism research, 24(3), 503-523. https://doi.org/10. 1016/S0160-7383(97)00009-1

Fornell, C., \& Larcker, D.F. (1981). Evaluating structural equation models with unobservable variables and measurement error. Journal of marketing research, 18(1), 39-50. https://doi.org/10.1177/002224378101800104

Fotis, J.N. (2015). The use of social media and its impacts on consumer behaviour: the context of holiday travel [online]. (Ph.D). Bournemouth University, UK. Access on 07-11-2020. https://eprints.bournemouth.ac.uk/22506/1/JOHN\%20FOTIS\%20-\%20PhD.pdf

Gifford, R., \& Nilsson, A. (2014). Personal and social factors that influence pro-environmental concern and behaviour: A review. International journal of psychology, 49(3), 141-157. https://doi.org/10.1002/ijop.12034

Goh, K.Y., Heng, C.S., \& Lin, Z. (2013). Social media brand community and consumer behavior: Quantifying the relative impact of user-and marketer-generated content. Information systems research, 24(1), 88-107. https://doi.org/10.1287/isre.1120.0469

Gosling, E., \& Williams, K.J. (2010). Connectedness to nature, place attachment and conservation behaviour: Testing connectedness theory among farmers. Journal of environmental psychology, 30(3), 298-304. https://doi.org/10.1016/j.jenvp.2010.01.005

Hair, J.F. (2009). Multivariate data analysis: A Global Perspective (7th ed ed.): Upper Saddle River: Prentice Hall, NJ.

Han, H. (2015). Travelers' pro-environmental behavior in a green lodging context: Converging value-belief-norm theory and the theory of planned behavior. Tourism Management, 47, 164-177. https://doi.org/10.1016/j.tourman.2014.09.014

Han, H., \& Hwang, J. (2016). Cruise travelers' environmentally responsible decision-making: An integrative framework of goal-directed behavior and norm activation process. International journal of hospitality management, 53, 94-105. https://doi.org/10.1016/j.ijhm.2015.12.005

Haseeb, M., \& Azam, M. (2020). Dynamic nexus among tourism, corruption, democracy and environmental degradation: a panel data investigation. Environment, development and sustainability, 23(4), 5557-5575. https://doi.org/10.1007/s10668-020-00832-9

He, X., Hu, D., Swanson, S.R., Su, L., \& Chen, X. (2018). Destination perceptions, relationship quality, and tourist environmentally responsible behavior. Tourism management perspectives, 28, 93-104. https://doi.org/10.1016/j.tmp.2018.08.001

Hines, J.M., Hungerford, H.R., \& Tomera, A.N. (1987). Analysis and synthesis of research on responsible environmental behavior: A meta-analysis. The Journal of environmental education, 18(2), 1-8. https://doi.org/10.1080/00958964.1987.9943482

Ho, C.T., \& Gebsombut, N. (2019). Communication factors affecting tourist adoption of social network sites. Sustainability, $11,4198$. https://doi.org/10.3390/su11154198

Ho, C. I., \& Liu, Y. P. (2005). An exploratory investigation of web-based tourist information search behavior. Asia Pacific Journal of Tourism Research, 10(4), 351-360. https://doi.org/10.1080/10941660500363645

Hollander, J. B., \& Page, M. (2020). Community development and place attachment using an inductive social media approach. In Research Handbook on Community Development, 361-381: Edward Elgar Publishing https://doi.org/10.4337/9781788118477.00030

Huang, C.D., Goo, J., Nam, K., \& Yoo, C.W. (2017). Smart tourism technologies in travel planning: The role of exploration and exploitation. 54(6), 757-770. https://doi.org/10.1016/j.im.2016.11.010

Hvass, K.A., \& Munar, A.M. (2012). The takeoff of social media in tourism. Journal of vacation marketing, 18(2), 93-103. https://doi.org/10.1177/1356766711435978

Idumange, J. (2012). The social media as a platform for creating environmental awareness in the Niger Delta region. 3rd Environment Outreach Magazine Public Lecture and Environmental Awards, Effurun, Delta State, 28, 592-603.

Independent. (2018). Tourism is responsible for nearly one tenth of the world's carbon emissions. access on 16-11-2020. https://www. independent.co.uk/environment/tourism-climate-change-carbon-emissions-global-warming-flying-cars-transport-a8338946.html

Jacobsen, J.K.S., \& Munar, A.M. (2012). Tourist information search and destination choice in a digital age. Tourism management perspectives, 1, 39-47. https://doi.org/10.1016/j.tmp.2011.12.005

Jacoby, J. (2002). Stimulus-organism-response reconsidered: an evolutionary step in modeling (consumer) behavior. Journal of consumer psychology, 12(1), 51-57. https://doi.org/10.1207/S15327663JCP1201_05

Jahanishakib, F., \& Bakhshi, D. (2020). Regression analysis of environmental effective factors on tourists' behaviors in Birjand natural and cultural attractions. Journal Of Natural Environment, 73(2), 271-283.

Jani, D., \& Han, H. (2015). Influence of environmental stimuli on hotel customer emotional loyalty response: Testing the moderating effect of the big five personality factors. International journal of hospitality management, 44, 48-57. https://doi.org/10.1016/j.ijhm.2014.10.006

Javed, M., Tučková, Z., \& Jibril, A.B. (2020). The role of social dedia on tourists' behavior: An empirical analysis of millennials from the Czech Republic. Sustainability, 12(18), 7735. https://doi.org/10.3390/su12187735

Jin, T., Lin, V.S., \& Hung, K. (2014). China's generation Y's expectation on outbound group package tour. Asia Pacific Journal of Tourism Research, 19(6), 617-644. https://doi.org/10.1080/10941665.2013.806939

Johnson, N.L., Kotz, S., \& Balakrishnan, N. (1995). Continuous univariate distributions, volume 2 (Vol. 289): John wiley \& sons.

Jussila, J.J., Kärkkäinen, H., \& Leino, M. (2011). Benefits of social media in business-to-business customer interface in innovation. Paper presented at the Proceedings of the 15th International Academic MindTrek Conference: Envisioning Future Media Environments. 
Kaur, K. (2015). Social media creating digital environmental publics: Case of Lynas Malaysia. Public Relations Review, 41(2), $311-314$. https://doi.org/10.1016/j.pubrev.2014.12.005

Kiatkawsin, K., \& Han, H. (2017). Young travelers' intention to behave pro-environmentally: Merging the value-belief-norm theory and the expectancy theory. Tourism Management, 59, 76-88. https://doi.org/10.1016/j.tourman.2016.06.018

Kim, J., \& Lennon, S.. (2013). Effects of reputation and website quality on online consumers' emotion, perceived risk and purchase intention. Journal of Research in Interactive Marketing, 7(1), 33-56. https://doi.org/10.1108/17505931311316734

Kim, M.J., Lee, C.K., \& Jung, T. (2020). Exploring consumer behavior in virtual reality tourism using an extended stimulus-organismresponse model. Journal of Travel Research, 59(1), 69-89. https://doi.org/10.1177/0047287518818915

Kollmuss, A., \& Agyeman, J. (2002). Mind the gap: why do people act environmentally and what are the barriers to pro-environmental behavior? Environmental education research, 8(3), 239-260. https://doi.org/10.1080/13504620220145401

Kreag, G. (2001). The Impacts of Tourism (Vol. 13). University of Minnesota. USA, Minnesota Sea Grant.

Kyle, G., Graefe, A., Manning, R., \& Bacon, J. (2004). Effects of Place Attachment on Users' Perceptions of Social and Environmental Conditions in a Natural Setting. Journal of environmental psychology, 24, 213-225. https://doi.org/10.1016/j.jenvp.2003.12.006

Kyle, G.T., Absher, J.D., \& Graefe, A.R. (2003). The moderating role of place attachment on the relationship between attitudes toward fees and spending preferences. Leisure Sciences, 25(1), 33-50. https://doi.org/10.1080/01490400306552

Lebe, S.S., Mulej, M., Batat, W., \& Prentovic, S. (2014). Towards viral systems thinking: a cross-cultural study of sustainable tourism ads. Kybernetes, 43(3/4), 529-546. https://doi.org/10.1108/K-07-2013-0147

Lee, C.S., \& Ma, L. (2012). News sharing in social media: The effect of gratifications and prior experience. Computers in human behavior, 28(2), 331-339. https://doi.org/10.1016/j.chb.2011.10.002

Lee, J. S.H., \& Oh, C.O. (2018). The Causal Effects of Place Attachment and Tourism Development on Coastal Residents' Environmentally Responsible Behavior. Coastal management, 46(3), 176-190. https://doi.org/10.1080/08920753.2018.1451728

Lee, T.H. (2011). How recreation involvement, place attachment and conservation commitment affect environmentally responsible behavior. Journal of Sustainable tourism, 19(7), 895-915. https://doi.org/10.1080/09669582.2011.570345

Lee, T.H., \& Jan, F.H. (2015). The effects of recreation experience, environmental attitude, and biospheric value on the environmentally responsible behavior of nature-based tourists. Environmental management, 56(1), 193-208. https://doi.org/10.1007/s00267-015-0488-y

Lee, T.H., Jan, F.H., \& Huang, G. W. (2015). The influence of recreation experiences on environmentally responsible behavior: The case of Liuqiu Island, Taiwan. Journal of Sustainable tourism, 23(6), 947-967. https://doi.org/10.1080/09669582.2015.1024257

Lee, T.H., Jan, F.H., \& Yang, C.-C. (2013). Conceptualizing and measuring environmentally responsible behaviors from the perspective of community-based tourists. Tourism Management, 36, 454-468. https://doi.org/10.1016/j.tourman.2012.09.012

Li, Q., Li, X., Chen, W., Su, X., \& Yu, R. (2020). Involvement, place attachment, and environmentally responsible behaviour connected with geographical indication products. Tourism Geographies, 1-26. https://doi.org/10.1080/14616688.2020.1826569

Liu, C.J., \& Hao, F. (2020). The impact of social and ecological factors on environmentally responsible behavior. Journal of Cleaner Production, 254, 120173. https://doi.org/10.1016/j.jclepro.2020.120173

Lively, A. (2011). Is social media the missing key in urban sustainability. Access on 10-11-2020. http://eucenterillinois.blogspot. com/2011/11/is-social-media-missing-key-in-urban.html

Logar, I. (2010). Sustainable tourism management in Crikvenica, Croatia: An assessment of policy instruments. Tourism Management, 31(1), 125-135. https://doi.org/10.1016/j.tourman.2009.02.005

Lokocz, E., Ryan, R.L., \& Sadler, A.J. (2011). Motivations for land protection and stewardship: Exploring place attachment and rural landscape character in Massachusetts. Landscape and urban planning, 99(2), 65-76. https://doi.org/10.1016/j.landurbplan.2010.08.015

Mazaheri, E., Richard, M.O., \& Laroche, M. (2010). Investigating the moderating impact of hedonism on online consumer behavior. Journal of Global Academy of Marketing Science, 20(2), 123-134. https://doi.org/10.1080/12297119.2010.9730185

Mehrabian, A., \& Russell, J. A. (1974). An approach to environmental psychology: the MIT Press.

Mobley, C., Vagias, W. M., \& DeWard, S. L. (2010). Exploring additional determinants of environmentally responsible behavior: The influence of environmental literature and environmental attitudes. Environment and behavior, 42(4), 420-447. https://doi.org/10.1177/0013916508325002

Nalewajek, M., \& Macik, R. (2013). The role of social media in building awareness of responsible consumption. Paper presented at the Active Citizenship by Knowledge Management \& Innovation: Proceedings of the Management, Knowledge and Learning International Conference 2013, Make learn, Zadar, Croácia.

Netemeyer, R.G., Bearden, W.O., \& Sharma, S. (2003). Scaling procedures: Issues and applications: SAGE Publications https://doi.org/10.4135/9781412985772.

Oh, C.O., Lyu, S., \& Hammitt, W. (2012). Predictive Linkages between Recreation Specialization and Place Attachment. Journal of leisure research, 44, 70-87. https://doi.org/10.1080/00222216.2012.11950255

Oussa, E., Oussa, E., \& Makmee, P. (2021). Development of assessment criteria of social media marketing on purchase intention among social media users in cambodia: a mixed method research. Burapha University, Thailand. .http://ir.buu.ac.th/dspace/handle/1513/181

Payton, M.A., Fulton, D.C., \& Anderson, D.H. (2005). Influence of Place Attachment and Trust on Civic Action: A Study at Sherburne National Wildlife Refuge. Society \& Natural Resources, 18(6), 511-528. https://doi.org/10.1080/08941920590947940

Pietilä, M., \& Fagerholm, N. (2016). Visitors' place-based evaluations of unacceptable tourism impacts in Oulanka National Park, Finland. Tourism Geographies, 18(3), 258-279. https://doi.org/10.1080/14616688.2016.1169313

Rajaguru, R. (2014). Motion picture-induced visual, vocal and celebrity effects on tourism motivation: Stimulus organism response model. Asia Pacific Journal of Tourism Research, 19(4), 375-388. https://doi.org/10.1080/10941665.2013.764337

Riera, L.I., Ruiz, M.M.P., Zarco, J.A.I., \& Yusta, I.A. (2015). Assessing the influence of social media on tourists' motivations and image formation of a destination. International Journal of Quality and Service Sciences, 7(4), 458-482. https://doi.org/10.1108/IJQSS-03-2014-0022

Robelia, B.A., Greenhow, C., \& Burton, L. (2011). Environmental learning in online social networks: Adopting environmentally responsible behaviors. Environmental education research, 17(4), 553-575. https://doi.org/10.1080/13504622.2011.565118

Scannell, L., \& Gifford, R. (2010). Defining place attachment: A tripartite organizing framework. Journal of environmental psychology, 30(1), 1-10. https://doi.org/10.1016/j.jenvp.2009.09.006

Scannell, L., \& Gifford, R. (2010). The relations between natural and civic place attachment and pro-environmental behavior. Journal of environmental psychology, 30(3), 289-297. https://doi.org/10.1016/j.jenvp.2010.01.010

Schober, P., Boer, C., \& Schwarte, L.A. (2018). Correlation coefficients: appropriate use and interpretation. Anesthesia \& Analgesia, 126(5), 1763-1768. https://doi.org/10.1213/ane.0000000000002864 
Schumacker, E., \& Lomax, G. (2016). A Beginner's Guide to Structural Equation Modeling. (4th ed.), New York, NY: Routledge https://doi.org/10.4324/9781410610904.

Severo, E.A., Guimarães, J.C.F.D., Dellarmelin, M.L., \& Ribeiro, R.P. (2019). The Influence of Social Networks on Environmental Awareness and the Social Responsibility of Generations. BBR. Brazilian Business Review, 16(5), 500-518. https://doi.org/10.15728/bbr.2019.16.5.5

Shandas, V., \& Messer, W.B. (2008). Fostering green communities through civic engagement: community-based environmental stewardship in the Portland area. Journal of the American Planning Association, 74(4), 408-418. https://doi.org/10.1080/01944360802291265

Sivek, D.J., \& Hungerford, H. (1990). Predictors of responsible behavior in members of three Wisconsin conservation organizations. The Journal of environmental education, 21(2), 35-40. https://doi.org/10.1080/00958964.1990.9941929

Smith-Sebasto, N.J. (1992). Design, development, and validation of an instrument to assess the relationship between locus of control of reinforcement and environmentally responsible behavior in university undergraduate students. The Ohio State University, USA,

Smith-Sebasto, N.J., \& D'Costa, A. (1995). Designing a Likert-type scale to predict environmentally responsible behavior in undergraduate students: A multistep process. The Journal of environmental education, 27(1), 14-20. https://doi.org/10.1080/00958964.1995.9941967

Snepenger, D., Meged, K., Snelling, M., \& Worrall, K. (1990). Information search strategies b y destination-naive tourists. Journal of Travel Research, 29(1), 13-16. https://doi.org/10.1177/004728759002900104

Song, Y., Qin, Z., \& Yuan, Q. (2019). The impact of eco-label on the young Chinese generation: The mediation role of environmental awareness and product attributes in green purchase. Sustainability, 11(4), 973. https://doi.org/10.3390/su11040973

Sparks, B.A., Perkins, H.E., \& Buckley, R. (2013). Online travel reviews as persuasive communication: The effects of content type, source, and certification logos on consumer behavior. Tourism Management, 39, 1-9. https://doi.org/10.1016/j.tourman.2013.03.007

*** Statista. (2020). Number of social media users. Access on 7th November 2020. https://www.statista.com/statistics/278414/numberof-worldwide-social-network-users/

Steg, L., \& Vlek, C. (2009). Encouraging pro-environmental behaviour: An integrative review and research agenda. Journal of environmental psychology, 29(3), 309-317. https://doi.org/10.1016/j.jenvp.2008.10.004

Stern, P.C. (2000). New environmental theories: toward a coherent theory of environmentally significant behavior. Journal of social issues, 56(3), 407-424. https://doi.org/10.1111/0022-4537.00175

Su, L., Hsu, M.K., \& Boostrom Jr, R. E. (2020). From recreation to responsibility: Increasing environmentally responsible behavior in tourism. Journal of Business Research, 109, 557-573. https://doi.org/10.1016/j.jbusres.2018.12.055

Su, L., Hsu, M.K., \& Marshall, K.P. (2014). Understanding the relationship of service fairness, emotions, trust, and tourist behavioral intentions at a city destination in China. Journal of Travel \& Tourism Marketing, 31(8), 1018-1038. https://doi.org/10.1080/10548408.2014.892466

Su, L., Huang, S.S., \& Pearce, J. (2018). How does destination social responsibility contribute to environmentally responsible behaviour? A destination resident perspective. Journal of Business Research, 86, 179-189. https://doi.org/10.1016/j.jbusres.2018.02.011

Sujata, M., Khor, K.S., Ramayah, T., \& Teoh, A.P. (2019). The role of social media on recycling behaviour. Sustainable Production and Consumption, 20, 365-374. https://doi.org/10.1016/j.spc.2019.08.005

Taha, A.V., Pencarelli, T., Škerháková, V., Fedorko, R., \& Košíková, M. (2021). The Use of Social Media and Its Impact on Shopping Behavior of Slovak and Italian Consumers during COVID-19 Pandemic. Sustainability, 13(4), 1710. https://doi.org/10.3390/su13041710

Tseng, W.T., Dörnyei, Z., \& Schmitt, N. (2006). A new approach to assessing strategic learning: The case of self-regulation in vocabulary acquisition. Applied linguistics, 27(1), 78-102. https://doi.org/10.1093/applin/ami046

Uehara, K.E., Nakatani, J., \& Hirao, M. (2016). Analysis of factors influencing consumers' proenvironmental behavior based on life cycle thinking. Part I: effect of environmental awareness and trust in environmental information on product choice. Journal of Cleaner Production, 117, 10-18. https://doi.org/10.1016/j.jclepro.2015.12.030

Ujang, N., \& Zakariya, K. (2015). Place Attachment and the Value of Place in the Life of the Users. Procedia-Social and Behavioral Sciences, 168, 373-380. https://doi.org/10.1016/j.sbspro.2014.10.243

Vaske, J.J., \& Kobrin, K.C. (2001). Place attachment and environmentally responsible behavior. The Journal of environmental education, 32(4), 16-21. https://doi.org/10.1080/00958960109598658

Voramontri, D., \& Klieb, L. (2019). Impact of social media on consumer behaviour. International Journal of Information and Decision Sciences, 11(3), 209-233. https://doi.org/10.1504/IJIDS.2019.101994

Warzecha, C.A., \& Lime, D.W. (2001). Place Attachment in Canyonlands National Park: Visitors' Assessment of Setting Attributes on the Colorado and Green Rivers. Journal of Park \& Recreation Administration, 19(1), 59-78.

Wohlwill, J.F. (1976). Environmental aesthetics: The environment as a source of affect. In Human behavior and environment, 37-86, Springer. https://doi.org/10.1007/978-1-4684-2550-5_2.

Xiang, Z., \& Gretzel, U. (2010). Role of social media in online travel information search. Tourism Management, 31(2), $179-188$. https://doi.org/10.1016/j.tourman.2009.02.016

Xu, J., \& Han, R. (2019). The influence of place attachment on pro-environmental behaviors: The moderating effect of social media. International Journal of Environmental Research and Public Health, 16(24), 5100. https://doi.org/10.3390/ijerph16245100

Yuksel, A., Yuksel, F., \& Bilim, Y. (2010). Destination attachment: Effects on customer satisfaction and cognitive, affective and conative loyalty. Tourism Management, 31(2), 274-284. https://doi.org/10.1016/j.tourman.2009.03.007

Zeng, B., \& Gerritsen, R. (2014). What do we know about social media in tourism? A review. Tourism management perspectives, 10, 2736. https://doi.org/10.1016/j.tmp.2014.01.001

Zgolli, S., \& Zaiem, I. (2018). The responsible behavior of tourist: The role of personnel factors and public power and effect on the choice of destination. Arab Economic and Business Journal, 13(2), 168-178. https://doi.org/10.1016/j.aebj.2018.09.004

Zhou, X., Tang, C., Lv, X., \& Xing, B. (2020). Visitor engagement, Relationship quality, and Environmentally responsible behavior. International Journal of Environmental Research and Public Health, 17(4), 1151. https://doi.org/10.3390/ijerph17041151

***Independent. (2018). Tourism is responsible for nearly one tenth of the world's carbon emissions. Access on 16-11-2020. https://www.independent.co.uk/environment/tourism-climate-change-carbon-emissions-global-warming-flying-cars-transport-a 8338946 .html

*** Statista. (2020). Number of social media users. Access on 07.11.2020. https://www.statista.com/statistics/278414/number-ofworldwide-social-network-users/

*** UNEP. (2019). Paradise lost? Travel and tourism industry takes aim at plastic pollution but more action needed. Access on 16-11-2020. https://www.unenvironment.org/news-and-stories/story/paradise-lost-travel-and-tourism-industry-takes-aim-plastic-pollution-more

***UNEP. (2019). Paradise lost? Travel and tourism industry takes aim at plastic pollution but more action needed access on 16.11.2020. https://www.unenvironment.org/news-and-stories/story/paradise-lost-travel-and-tourism-industry-takes-aim-plastic-pollution-more 